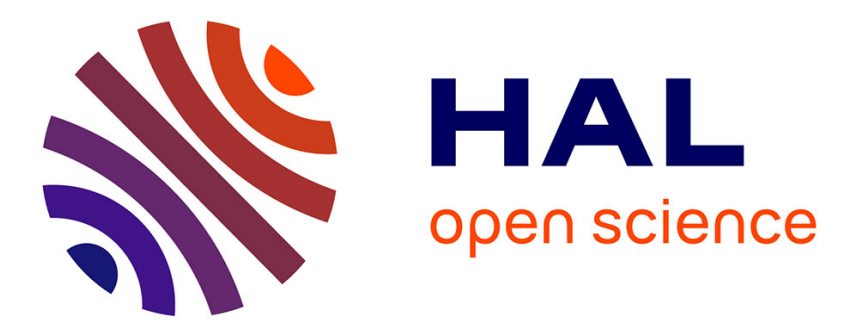

\title{
Comparison of extraction conditions for milk and hen's egg allergens
}

\author{
Mirva Steinhoff, Markus Fischer, Angelika Paschke
}

\section{To cite this version:}

Mirva Steinhoff, Markus Fischer, Angelika Paschke. Comparison of extraction conditions for milk and hen's egg allergens. Food Additives and Contaminants, 2011, pp.1. 10.1080/19440049.2010.545957 . hal-00670743

\section{HAL Id: hal-00670743 \\ https://hal.science/hal-00670743}

Submitted on 16 Feb 2012

HAL is a multi-disciplinary open access archive for the deposit and dissemination of scientific research documents, whether they are published or not. The documents may come from teaching and research institutions in France or abroad, or from public or private research centers.
L'archive ouverte pluridisciplinaire HAL, est destinée au dépôt et à la diffusion de documents scientifiques de niveau recherche, publiés ou non, émanant des établissements d'enseignement et de recherche français ou étrangers, des laboratoires publics ou privés. 


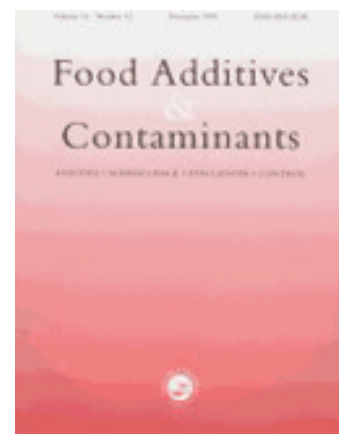

\section{Comparison of extraction conditions for milk and hen's egg allergens}

\begin{tabular}{|r|l|}
\hline Journal: & Food Additives and Contaminants \\
\hline Manuscript ID: & TFAC-2010-207.R1 \\
\hline Manuscript Type: & Original Research Paper \\
\hline Author: & 25-Nov-2010 \\
\hline Complete List of Authors: & $\begin{array}{l}\text { Steinhoff, Mirva; Food Chemistry, Chemistry, University of } \\
\text { Hamburg } \\
\text { Fischer, Markus; Food Chemistry, Chemistry, University of Hamburg } \\
\text { Paschke, Angelika; University of Hamburg, Chemistry, Food } \\
\text { Chemistry }\end{array}$ \\
\hline Methods/Techniques: & Extraction, Immunoassays \\
\hline Additives/Contaminants: & Allergens, Process contaminants \\
\hline Food Types: & Bakery products, Eggs, Milk \\
\hline &
\end{tabular}

\section{SCHOLARONE}

Manuscripts 


\section{Comparison of extraction conditions for milk and hen's egg}

2 allergens

\section{MIRVA STEINHOFF, MARKUS FISCHER, ANGELIKA PASCHKE-KRATZIN ${ }^{1}$}

University of Hamburg, Institute of Food Chemistry, Grindelallee 117, 20146 Germany;

\section{Abstract}

9 The evaluation of recovery rates by extracting dried milk and egg powder using eleven different extractants gave approximately similar results for both foods. Compared to the other extraction solutions investigated, " $1 \%$ Tween 20 and $0.4 \%$ Triton X-100" and "4 \% SDS" are the most suitable extractants to isolate proteins of hen's egg or milk. Comparing calculated protein recovery rates of egg and milk powder extracts the results clearly indicated that the choice of a suitable extractant is of particular importance. Qualitative investigation of the extracts via LDS - PAGE followed by silver staining as well as immunoblotting confirmed the results of protein quantification. Hence, the immunoblots showed that the extraction agents had no negative influence on the antigenicity of the extracted allergenic proteins. In this study, variation of extraction temperature neither led to any benefit in extraction quality nor to degradation. Changing $\mathrm{pH}$ did not reveal any trends, but progressive protein hydrolysis under strong alkaline conditions. Evaluation of recovery rates as well as results of unspecific and specific staining of the extracts showed that an extraction time of one hour is sufficient for an appropriate sample preparation. For investigations with and without food matrix different results were obtained. In summary, wheat starch did not influence the extraction quality within all examined materials and different extractants. In contrast, using fat powder and dry cake mix, respectively, led to different results in the extraction procedure. When fat powder and dry cake mix were used as food matrices, some protein recovery rates decreased and

\footnotetext{
${ }^{1}$ angelika.paschke@uni-hamburg.de
} 
27 some increased depending on the allergen material. These results highlight the fact that the suitability of the extractant not only depends on the properties of the allergen but furthermore on the type of matrix containing the allergen.

Keywords: Food allergy, hidden allergens, extraction of allergens, hen's egg, cow's milk

\section{Introduction}

Cow's milk and hen's egg as well as their products belong to eight food or food groups which are responsible for about $90 \%$ of allergic reactions (Hefle and Taylor, 2004). The consumption of small amounts can already cause life-threatening or lethal reactions (Vieluf et al., 2002). Nevertheless, allergic persons can unintentionally consume allergenic material if these are unexpectedly part of a food product e.g. because of food contamination / cross contact within the manufacturing process (Hefle and Taylor, 2004). The threshold doses for triggering symptoms after ingestion of the offending food are strongly dependent on the patient's individual susceptibility and the allergic potential of the particular food. Clinical data shows that exposure to even about $1 \mathrm{mg}$ of the allergen can elicit adverse reactions up to anaphylactic shocks in individuals with IgE-mediated food allergies (Besler et al., 2001; Moneret-Vautrin and Kanny, 2004). The legislation on food labelling only concerns allergenic ingredients that are knowingly and deliberately added to food products.

50 The analytical proof of the presence of small amounts of allergens, must use a technique 51 sensitive enough to specifically detect the allergens in those amounts that might trigger 52 allergic reactions in sensitized individuals. The determining step in allergen detection is the 53 isolation of the allergens from the food which can be influenced by numerous factors. The 54 diversity of foods in terms of composition and texture as well may require appropriate 
extraction methods. The extraction solution must provide efficient isolation of the allergenic proteins from the sample into a liquid phase and minimize background effects due to nonspecific binding. In food many ingredients are available to participate in complex physical and chemical reactions with the allergenic proteins (Davis et al., 2001). Especially during the manufacturing process the matrix might cause covalent modification of proteins through food processing. As well as antigenicity, the extractability of allergens can be decreased in these reactions, they might be unchanged or even increased (Besler et al., 2001).

The aim of this study was to evaluate and compare extraction solutions for the isolation of milk and egg allergens. For this purpose extractability of allergenic proteins of dried milk powder, sweet whey, acid whey, whole egg, egg yolk and egg white with eleven different extraction agents was examined. Extractants were selected by collecting recipes already described in literature to isolate allergens. In addition, chosen extraction solutions represent a huge diversity in $\mathrm{pH}$, ionic strength, and detergent content. As extraction quality describing parameters protein yield, the composition of the proteins as well as the antigen patterns were determined. To evaluate, if food matrix influences the extractability of proteins, wheat starch, fat powder and an experimental dry cake mix were employed in the extraction experiments.

\section{Materials and Methods}

Reagents and materials

Milk powder, dried sweet whey, dried acid whey, whole egg powder, powdered egg yolk and powdered egg white were obtained from Kampffmeyer Food Innovation GmbH (Hamburg, Germany). Powdered egg white was purchased from Sigma-Aldrich Chemie GmbH (Munich, Germany). To obtain powdered egg yolk, liquid whole egg was separated mechanically and lyophilized referring to homogenization. Commercially available wheat starch (protein-free, Heinrich Klenk GmbH \& Co. KG, Schwebheim, Germany), fat powder (protein-free coconut oil, Kampffmeyer Food Innovation GmbH, Hamburg, Germany) and an experimental dry cake mix were used as matrix. The dry cake mix contained sucrose $(70.5 \%$, Kampffmeyer Food 
83 Innovation $\mathrm{GmbH}$, Hamburg, Germany), fat powder (17.7\%), wheat starch (9.8\%), sodium 84 hydrogen carbonate (1.6\%, Merck Chemicals, Darmstadt, Germany) and sodium chloride (0.4\%, Merck Chemicals, Darmstadt, Germany).

Sheep anti-casein serum and biotinylated rabbit anti-sheep serum were purchased from 88 antibodies-online $\mathrm{GmbH}$ (Aachen, Germany). Rabbit anti-whey and rabbit anti-ovalbumin 89 sera were both acquired from Sigma-Aldrich Chemie GmbH (Munich, Germany). Biotinylated 90 goat anti-rabbit antibodies were bought from Rockland (Gilbertsville, PA, USA) and 91 streptavidin-horseradish peroxidase was obtained from Bio-Rad Laboratories GmbH 92 (Munich, Germany). All other reagents were of analytical grade and purchased from Sigma93 Aldrich Chemie GmbH (Munich, Germany), Fluka (Buchs, Switzerland) and Serva 94 Electrophoresis GmbH (Heidelberg, Germany).

Composition of extractants

97 In this investigation, eleven different extractants were used to extract protein from dairy and 98 egg products: $\mathrm{A}$ : $0.01 \mathrm{M}$ phosphate-buffered saline containing $10 \mathrm{mM} \mathrm{Na} \mathrm{HPO}_{4}, 1 \mathrm{mM}$ $99 \mathrm{KH}_{2} \mathrm{PO}_{4}, 3 \mathrm{mM} \mathrm{KCl}$ and $140 \mathrm{mM} \mathrm{NaCl}, \mathrm{pH} 7.4$ (Schubert, 2003); B: $0.01 \mathrm{M}$ phosphate100 buffered saline containing $2 \mathrm{mM} \mathrm{NaH}_{2} \mathrm{PO}_{4}, 8 \mathrm{mM} \mathrm{Na}_{2} \mathrm{HPO}_{4}$ and $150 \mathrm{mM} \mathrm{NaCl}$, pH 7.4 (Hefle 101 and Lambrecht, 2004); C: $0.01 \mathrm{M}$ phosphate-buffered saline containing $150 \mathrm{mM} \mathrm{NaCl}, 10$ $102 \mathrm{mM} \mathrm{Na}_{2} \mathrm{HPO}_{4}, \mathrm{pH} 7.2$ (Leduc et al., 1999); D: physiological saline containing $150 \mathrm{mM} \mathrm{NaCl}$, 103 pH 6.6 (Langeland, 1982); E: $1 \%$ Tween $20^{\circledR}, \mathrm{pH} 6.0$ (Fernandez et al., 1999); F : 8 M urea, 104 pH 7.7 (Natarajan et al., 2005); G: 100 mM acetate buffer, pH 3.8 (Hirose et al., 2004); H: 86 $105 \mathrm{mM} \mathrm{NaCl}, 30 \mathrm{mM} \mathrm{NaHCO}$, $0.4 \%$ phenol, pH 8.2 (Coca, 1922); I: $1 \%$ Tween $20{ }^{\circledR}, 0.4 \%$ 106 Triton $\mathrm{X}-100^{\circledR}, 280 \mathrm{mM} \mathrm{NaCl}, 40 \mathrm{mM} \mathrm{NaH}_{2} \mathrm{PO}_{4}, \mathrm{pH} 7.4$ (Yeung et al., 2000); J: 4 \% Sodium 107 dodecyl sulphate, pH 8.5 (Kato et al., 2001a); K bidestilled water. All extraction solutions 108 were prepared using bidestilled water and were stabilized with $0.02 \% \mathrm{NaN}_{3}$. For 109 investigations with the aim to optimize $\mathrm{pH}$-value of selected extractants, $\mathrm{J}(\mathrm{pH} 8.5)$ and I $(\mathrm{pH}$ 
110 7.4) were additionally prepared with $\mathrm{pH}$-values adjusted to 10.5 and 12.5 and 9.4 and 11.4 , 111 respectively. Adjustment of $\mathrm{pH}$ was carried out with $0.1 \mathrm{M} \mathrm{NaOH}$.

113 Protein isolation

114 Principally, extraction procedure was carried out as follows. According to the protein content 115 measured via Kjeldahl method, $30 \mathrm{mg}$ milk powder, $100 \mathrm{mg}$ sweet whey, $100 \mathrm{mg}$ acid whey, $11625 \mathrm{mg}$ whole egg powder, $15 \mathrm{mg}$ dried egg white and $30 \mathrm{mg}$ dried egg yolk, respectively, 117 were weighed into a $50 \mathrm{~mL}$ polypropylene centrifuge tube (Nunc $\mathrm{GmbH}$ \& Co. KG, 118 Wiesbaden, Germany). In the case of matrix addition, $1 \mathrm{~g}$ matrix (wheat starch, fat powder, 119 dry cake mix) was also weight in the centrifuge tube and the dry material was mixed $5 \mathrm{sec}$ 120 with a vortex mixer (VWR international, Darmstadt, Germany; mixing frequency 2,500 rpm) 121 before extractant was added. Protein extraction was carried out by suspending sample 122 material with $20 \mathrm{~mL}$ of extraction solution. The homogenate was extracted over night on a 123 laboratory shaker (Bühler, Tübingen, Germany; shaking frequency $150 \mathrm{rpm}$ ) at room 124 temperature and centrifuged afterwards $30 \mathrm{~min}$ at 10,000 rpm (Sigma-Aldrich Chemie $125 \mathrm{GmbH}$, Munich, Germany). Solids were removed by filtration (Macherey-Nagel GmbH \& Co. 126 KG, Düren, Germany; filter paper grade MN 616). Investigations with the aim to optimize 127 extraction temperature were additionally carried out at $4{ }^{\circ} \mathrm{C}$ on a laboratory shaker in a 128 standard refrigerator (Linde, München, Germany) and at $40{ }^{\circ} \mathrm{C}$ using a laboratory incubator 129 (IRC-1-U Clim-o-shake, Adolf Kühner AG, Birsfelden, Swiss; shaking frequency 150 rpm).

130 For examination of extraction duration, protein isolation as described above was interrupted 131 after 0.5, 1, 2, 4 and 8 hours. Each extraction process was performed in triplicate.

133 Protein quantification

134 Absolute protein content of used dry materials was determined via Kjeldahl method analysing

135 the nitrogen content. The conversion factors from nitrogen to protein were as recommended 1366.38 (dairy products) and 6.25 (egg products), respectively. The protein concentration of the 137 extracts was measured photometrically according to the method of Lowry (1951) using 
138 bovine serum albumin (BSA) and ovalbumin respectively as standards. Photometrical

139 measurement of protein content was favoured over Kjeldahl method because in comparison

140 the latter is of high expenditure of time and technical effort. The Folin's reagent used in the

141 Lowry method consists amongst others of phosphomolybdic/phosphotungstic acid. A

142 standard curve was produced for each run using a $500 \mathrm{mg} / \mathrm{L}$ protein solution prepared

143 using the appropriate extractant. The protein content of the extracts prepared with "Coca's

144 solution" (containing phenol) was measured by the method of Bradford (1976) because

145 phenol interferes with the Lowry method. Bradford reagent consists of Coomassie Brilliant

146 Blue G-250 and phosphoric acid. Quantitative assessments of extracts and standards were

147 performed by measuring optical density at $720 \mathrm{~nm}$ (Lowry method) and $590 \mathrm{~nm}$ (Bradford

148 method) using a spectrometer (MRX Plate Reader, Dynex Technologies, Frankfurt,

149 Germany).

150

151 Lithium Dodecyl Sulphate-Polyacrylamide Gel Electrophoresis (LDS - PAGE)

152 Proteins were separated with precast NuPAGE ${ }^{\circledR}$ Bis-Tris $12 \%$ gels (Invitrogen GmbH,

153 Karlsruhe, Germany) under denaturing conditions at 200 V for 55 min using NuPAGE ${ }^{\circledR}$

154 MOPS [3-(N-morpholino) propanesulfonic acid] SDS running buffer (Invitrogen $\mathrm{GmbH}$,

155 Karlsruhe, Germany). Following the manufacturers instructions obtained extracts were

156 diluted 1:1 in LDS (lithium dodecyl sulphate) sample buffer (Invitrogen $\mathrm{GmbH}$, Karlsruhe,

157 Germany) containing dithiothreitol for reduction at room temperature. Sample load was $20 \mu \mathrm{L}$

158 per lane. Proteins were further silver stained or transferred by blotting method onto a

159 nitrocellulose membrane.

160

$161 \quad$ Silver staining

162 The proteins were detected by standard silver staining procedure according to (Heukeshoven 163 and Dernick, 1986) following LDS - PAGE. After fixing the gel (30\% ethanol, $10 \%$ acetic 164 acid in water; $30 \mathrm{~min})$ it was sensitized in $0.1 \%$ sodium thiosulfate $\left(0.1 \% \mathrm{Na}_{2} \mathrm{~S}_{2} \mathrm{O}_{3}, 30 \%\right.$ 165 ethanol, $6.8 \%$ sodium acetate in water). After washing with water the gel was incubated for $16620 \mathrm{~min}$ in $0.2 \%$ silver nitrate solution $\left(0.2 \% \mathrm{AgNO}_{3}, 0.02 \%\right.$ formaldehyde in water). 
167 Afterwards the gel was developed in $2.5 \%$ sodium carbonate $\left(2.5 \% \mathrm{Na}_{2} \mathrm{CO}_{3}, 0.01 \%\right.$

168 formaldehyde in water). Staining was terminated using $1.8 \%$ EDTA-solution (1.8\%

169 ethylenediaminetetraacetate in water).

\section{Immunoblotting}

172 The isolated proteins separated by LDS - PAGE were transferred electrophoretically from the

173 gel onto the surface of a nitrocellulose membrane ( $2 \mu \mathrm{m}$, Whatman, Kent, UK) using semidry

174 blotting method. In brief, dried membranes were blocked with blocking solution (containing

$1750.5 \%$ Tween $20{ }^{\circledR}, 0.9 \%$ sodium chloride and $0.6 \%$ tris base) and incubated overnight with 176 sheep anti-casein $(1: 400)$, rabbit anti-whey $(1: 200000)$ and rabbit anti-ovalbumin

$177(1: 200000)$ antibodies, respectively, at room temperature. Membranes were then incubated 178 consecutively with biotinylated rabbit anti-sheep serum (1:100000; milk powder) or 179 biotinylated goat anti-rabbit serum (1:7500; powdered sweet whey, powdered acid whey,

180 whole egg powder, powdered egg yolk, powdered egg white) and streptavidin - horseradish 181 peroxidase. Staining solution containing TMB and DONS $\left(0.06 \% 3,3^{\prime}, 5,5^{\prime}\right.$ -

182 Tetramethylbenzidine, $0.2 \%$ dioctylsodiumsulphosuccinate, $25 \%$ ethanol, $0.7 \%$ citric acid, $1 \% \mathrm{Na}_{2} \mathrm{HPO}_{4}$ in water) was used for staining.

\section{Results}

\section{Protein quantification}

187 Protein recovery rates in the extracts were estimated by relating theoretical calculated

188 protein content measured via the Kjeldahl method to total protein yield of the extract 189 measured with Lowry or Bradford method (data not shown). The estimated recovery rates 190 are presented in Table 1 and Table 2. Extracting milk proteins from milk powder, recovery 191 rates range from 69 to $109 \%$ except for solution G yielding $16 \%$ protein. Highest recoveries

192 in protein isolation were achieved using solution I and $\mathrm{J}$ as extractants. Estimated recovery 193 rates for extraction of milk proteins from milk powder in dry cake mix ranged from 40 to $87 \%$ 194 except for solution G recovering $14 \%$ protein. Within these extracts, extractants B, D and J 195 gave the highest protein recoveries. Extracting proteins from milk powder in wheat starch 
196 and fat powder, the highest protein contents were obtained in the extracts prepared using

197 solution I, J and C or I and D, respectively (Table 1).

199 For all the egg materials which were examined, the extraction agents I and $\mathrm{J}$ aqueous solution 200 gave the highest protein yields (Table 2). In contrast to the extractants mentioned above, the 201 protein contents of the extracts prepared using saline solutions (A, B, C, D), G or H to extract 202 egg proteins from egg material led to recovery rates lower than $30 \%$. Where egg proteins 203 were isolated from egg powder in dry cake mix, solutions I and $\mathrm{J}$ gave the highest protein 204 recovery rates. Extracting proteins from egg material in wheat starch and fat powder as food 205 matrix, the highest protein contents were measured in the extracts prepared using solutions I 206 and J. But also $\mathrm{E}$ achieved high recovery of protein from egg material in wheat starch (Table 207 2).

209 In this study, optimization of $\mathrm{pH}$-value of extractants as well as extraction temperature was 210 carried out. Therefore, solution I $(\mathrm{pH} 7.4)$ and J ( $\mathrm{pH}$ 8.5) were additionally prepared having a $211 \mathrm{pH}$ of 9.4 and $11.4(\mathrm{I})$ as well as 10.5 and $12.5(\mathrm{~J})$, respectively. Extraction procedures were 212 simultaneously performed at three different extraction temperatures $\left(4{ }^{\circ} \mathrm{C}, \mathrm{RT}=\right.$ room 213 temperature and $40^{\circ} \mathrm{C}$ ). The estimated recovery rates are presented in Tables 3 and 4. 214 Comparing the protein yields there is not much of a difference. The deviation of the obtained 215 recovery rates is of the order of the calculated standard deviation.

217 With the aim to investigate optimum extraction duration, extraction procedures were 218 performed at different extraction temperatures using solution I $(\mathrm{pH} 7.4)$ and $\mathrm{J}(\mathrm{pH} 8.5)$ as 219 extractants to isolate milk and egg proteins from milk powder and whole egg powder and 220 from wheat starch and cake mix, respectively. Extraction procedures were stopped after $22130 \mathrm{~min}, 1 \mathrm{~h}, 2 \mathrm{~h}, 4 \mathrm{~h}$ and $8 \mathrm{~h}$ and protein contents were measured subsequently. Resulting 222 recovery rates are shown in Tables 5 and 6 . Regardless of extractant and extraction 
223 temperature there is not much of a difference comparing protein recoveries. The extracts 224 prepared of solution $\mathrm{J}$ have slightly higher protein contents than those made of by solution I. 225

Lithium Dodecyl Sulphate-Polyacrylamide Gel Electrophoresis (LDS - PAGE)

227 The composition of the isolated protein extracts were analyzed by electrophoretic separation 228 and silver staining. Comparison of (i) the number of protein bands and (ii) the intensities of 229 characteristic protein bands illustrates considerable protein diversity between the examined 230 extracts. LDS - PAGE and silver staining patterns of proteins extracted from egg powder and 231 milk powder using different extractants are shown in Figure 1. Those extracts prepared from 232 egg powder using solution I, J and E gave particularly strong stained bands of conalbumine, 233 ovalbumine and ovomucoid. Extracts prepared using solution $\mathrm{G}$ or $\mathrm{H}$ gave weakly stained 234 bands of characteristic egg proteins. Similar results were obtained extracting powdered dairy 235 products. The extractants I, J and E gave strongly stained bands of characteristic milk 236 proteins $\alpha$-lactalbumin, B-lactoglobulin and casein, whilst solution $\mathrm{G}$ gave weakly detected 237 bands representing characteristic milk proteins. Analysis of protein patterns of extracts 238 obtained extracting allergen material out of food matrix did not reveal wide differences in 239 band intensity of characteristic milk and egg allergens.

241 The influence of the $\mathrm{pH}$-value of the extractants was investigated.. Solution I was prepared 242 having $\mathrm{pH}$-values of $7.4,9.4$ and 11.4 , respectively. The $\mathrm{pH}$-value of solution $\mathrm{J}$ was adjusted 243 to $8.5,10.5$ and 12.5 , respectively. Detection of the electrophoretically separated extracts via 244 silver staining demonstrated that extracted proteins out of egg products and milk products led 245 to similar results. Figure 2 shows the LDS - PAGE and silver staining patterns of proteins, 246 adjusted to different $\mathrm{pH}$-values and used for extraction at $4{ }^{\circ} \mathrm{C}$, room temperature and $40{ }^{\circ} \mathrm{C}$. 247 Comparing the band intensities of the characteristic proteins in the extracts prepared with 248 solution I pH 7.4 and $\mathrm{pH} 9.4$ no differences appeared. Likewise, the band intensities of the 249 characteristic proteins in the extracts obtained using solution $\mathrm{J} \mathrm{pH} 8.5$ were as strong as 250 those prepared at $\mathrm{pH}$ 10.5. Any characteristic proteins could be visualized in the extracts 
251 made of solution $\mathrm{J}$ with a pH of 12.5 . Conversely, any characteristic proteins detected after 252 electrophoretic separation of the extracts made from solution I with a $\mathrm{pH}$ of 11.4 or the 253 detection of the characteristic proteins was much weaker.

255 The band intensities obtained via silver staining of milk and egg proteins isolated at different 256 temperatures were almost identical. Extracts obtained at the end of varied extraction 257 durations using solution $\mathrm{I}(\mathrm{pH}$ 7.4) and $\mathrm{J}(\mathrm{pH}$ 8.5) were electrophoretically separated and 258 proteins were detected via silver staining. Regardless of extractant and extracted material, 259 band intensities of characteristic proteins did not differ in terms of extraction duration (data 260 not shown).

\section{Immunoblotting}

263 Whether the estimated extractants ensure comprehensive isolation of intact allergens 264 specific immunochemical staining on nitrocellulose membrane after LDS-PAGE and 265 Western Blotting was performed (Figures 3 and 4). The extracts derived with solution I, J and 266 E present most strongly stained bands of ovalbumine compared to solutions $\mathrm{G}$ and $\mathrm{H}$ in the 267 immunoblots. The results of unspecific staining procedure as well as the determination of the 268 protein concentration are reflected in the results of immunochemical staining. Rabbit anti269 ovalbumin antibody used for detection of albumin also detects conalbumin (76 kDa) as 270 characteristic egg protein. Quite similar results were obtained by immunochemical detection 271 of milk proteins. Band intensities of milk proteins of purchased extracts looked rather similar 272 to the extracts described in this paper and Immunoblots showed only slight variations in 273 protein recovery rates. Anti-casein antibody used for detection of casein also detects bovine 274 serum albumin (BSA; $76 \mathrm{kDa})$ as characteristic milk protein.

276 The influence of wheat starch and dry cake mix on extraction efficiency and quality was 277 investigated by comparing the extract properties prepared with matrix addition and without as 278 described above. Addition of $8 \mathrm{M}$ urea as extractant to wheat starch or dry cake mix 
279 containing samples caused a strong enhancement of extract viscosity. Those solutions were 280 unemployable for further analysis. Band intensities referring to silver and immunochemical 281 staining do not differ noteworthy comparing the extracts made with matrix addition or without 282 (Figures 3 and 4). Considering dilution factors, extracts of solution I, J as well as E present 283 most strongly stained bands of ovalbumine compared to solutions $G$ and $H$ in the 284 immunoblots. Purchased extracts showed similar band intensities. The immunoblots affirm 285 the slight variation in protein recovery rates obtained for extracts made of dairy products.

287 Comparing the band intensities of the characteristic proteins in the extracts prepared with 288 solution $\mathrm{I}(\mathrm{pH} 7.4$ and $\mathrm{pH} 9.4)$ and $\mathrm{J}(\mathrm{pH} 8.5$ and 10.5), respectively, no differences appeared. Any characteristic proteins could be visualized in the extracts made of solution $\mathrm{J}$ pH 12.5 whilst the detection of the characteristic proteins extracted via solution I" pH 11.4 292

The band intensities obtained via immunochemical staining of milk and egg proteins isolated at different temperatures were almost identical. Regardless of extractant and extracted material, the band intensity of the characteristic proteins did not differ in terms of extraction 296 duration (data not shown). was much weaker.

\section{Discussion}

The ultimate prerequisite for sensitive analytical allergen detection is an efficient and reliable extraction method.

\section{Protein recovery rates}

Protein recovery rates were calculated by comparing the total protein concentration of the food sample with the protein yields of the extracts. The photometric detection, which was much more suitable for the screening of the extracts than the Kjeldahl procedure, only provides a relative but not an absolute quantification of the proteins. Nevertheless, the relative quantification was sufficient to assess the efficiency of the different extractants. 
308 Ranking the best extractant

309 The evaluation of recovery rates of extracted milk and egg material using eleven different 310 solutions led to similar results. The solutions I and $\mathrm{J}$ achieved the highest protein yields.

311 In the case of milk samples, the extractants had only minor impact on the extraction

312 efficiency. On the other hand, the extraction efficiency of egg material was much more

313 sensitive to the solution used for the protein extraction. The major difference between milk

314 and egg is the fat content. Because of the higher fat content of egg material, extractants

315 containing a detergent yielded higher protein recovery rates as compared to those without.

316 Emulsifying properties of egg-lecithin alone are not sufficient to extract egg powder properly.

317 These results clearly indicate that the composition of the extractant is of particular

318 importance for the efficiency and quality of the extract.

320 Quality of the protein extracts

321 Analysis of the extracts by LDS - PAGE followed by silver staining as well as immunoblotting 322 confirmed the results of protein quantification. Solution $\mathrm{I}$ as well as $\mathrm{J}$ led to the strongest 323 bands of characteristic milk and egg proteins, respectively. However, it has to be considered, 324 that silver staining generally possesses a lower sensitivity than photometrical protein 325 quantification. Slight variations concerning protein content in the extracts cannot be 326 discriminated after electrophoretical separation.

328 Detection of selected proteins by western blotting clearly demonstrated that both extraction 329 solutions had no negative influence onto the antigenicity of the extracted allergenic proteins.

330 Solution I and J are the most qualified extractants to isolate proteins of milk. In case of hen's 331 eggs, they are the only suitable solutions for the efficient extraction of proteins. Hence, hen's 332 egg is more sensitive to the extractant than milk.

334 Optimization of the extraction procedure: temperature and $\mathrm{pH}$ 
335 For the elucidation of the optimal temperature range, extractions were carried out at $4{ }^{\circ} \mathrm{C}$, 336 room temperature and $40{ }^{\circ} \mathrm{C}$. According to Howard et al. (1988) solubility of proteins can be 337 increased at $40{ }^{\circ} \mathrm{C}$ compared to lower temperatures. In contrast, thermal treatment of 338 allergens can influence conformational epitopes, which might loose their binding capacity to 339 specific antibodies (Besler et al., 2001). In the worst case, false-negative results are 340 obtained. In this study, variation of extraction temperature neither led to any benefit in 341 extraction quality nor to degradation. Comparison of recovery rates obtained via extraction at 342 different temperatures resulted in essentially similar results. Also unspecific staining as well 343 as immunoblots did not show any differences in band intensity comparing the extracts 344 prepared at different extraction temperature. The influence of $\mathrm{pH}$-values of extractants was 345 investigated using solution I and J prepared having different $\mathrm{pH}$-values. Solubility of proteins 346 strongly depends on the $\mathrm{pH}$-value of the medium. Proteins have minimum solubility in water 347 or salt solutions at the $\mathrm{pH}$ which corresponds to their isoelectric point (pl). Because milk 348 proteins as well as egg proteins have pl lower than 7 (except lysozyme), solution I ( $\mathrm{pH} 7.4$ ) 349 was additionally prepared having a pH of 9.4 and 11.4 and solution $\mathrm{J}(\mathrm{pH} 8.5)$ was prepared 350 having $\mathrm{pH}$-values of 10.5 and 12.5. In this study, evaluation of the influence of the protein 351 content in the extracts changing the $\mathrm{pH}$ did not show any tendencies. In contrast, analysis of 352 unspecific staining of the electrophoretically separated extracts demonstrated, that solution I 353 with a pH of 11.4 caused a partially hydrolysis of the proteins, whilst solution $\mathrm{J}$ with a pH of 35412.5 brought the proteins about to a total hydrolysis. Alkaline hydrolysis of proteins causes 355 progressive disintegration up to small peptides so that they are not detectible neither via 356 unspecific nor specific staining procedure. As a consequence, these extractants are not 357 applicable for further analysis damaging allergens antigenicity, although, solution I pH 7.4 358 and 9.4 as well as $\mathrm{J} \mathrm{pH} 8.5$ and 10.5 did not show this hydrolysis effect in the immunoblots.

360 Optimization of the extraction duration

361 To establish an extraction procedure in routine analyses, sample preparation should not be 362 too time-consuming. Otherwise, extraction duration has to guarantee maximum recovery of 
363 proteins. Evaluation of recovery rates, results of unspecific and specific staining of the

364 extracts showed that an extraction time of 1 hour is sufficient for an appropriate sample 365 preparation.

367 Food matrix

368 Comparing the results of qualitative and quantitative investigations of extraction of milk and 369 egg allergens out of certain dried milk and egg products with and without the presence of 370 several other food matrices, different findings were obtained. In summary, wheat starch 371 influences the extraction yield and the extraction quality with regard to the protein and 372 antigen pattern for all materials which were tested and for different extractants. In contrast, 373 using fat powder and dry cake mix, respectively, different extraction procedures led to 374 different results. Whilst fat powder did not influence recovery rates of milk powder, for sweet 375 whey and whole egg powder, up to twice as much protein was isolated from powdered egg 376 yolk. However, isolation of egg proteins from egg yolk combined with dry cake mix resulted 377 in protein recovery rates quite similar as those obtained for extracts without any matrix. On 378 the other hand extraction of proteins from whey as well as powdered egg white blended with 379 fat powder and dry cake mix, respectively, for some extractants lower protein recovery rates 380 were found. Detection of electrophoretically separated proteins confirmed the results of 381 protein quantification in giving weaker stained bands. These results highlight the fact that the 382 suitability of extractant not only depends on allergen properties but furthermore on the 383 surrounding food matrix.

385 What is the best procedure?

386 In this study, in the case of isolating proteins out of milk material " $1 \%$ Tween 20 and $0.4 \%$ 387 Triton X-100" pH 7.4 was the most suitable extraction agent. To extract egg proteins out of 388 egg material the best results were obtained using $4 \%$ SDS aqueous solution at $\mathrm{pH} 8.5$. If the 389 allergens are to be extracted out of complex food matrices containing sugars, fat and 390 proteins, the extractant mentioned above are still suitable, but partly less quantitative. In the 
391 case of egg allergens in a starch and fat containing matrix Tween $20{ }^{\circledR}$ as extractant gave 392 high protein recoveries. Regardless of allergen material and food matrix, carrying out the 393 extraction procedure for 1 hour at room temperature guarantees high protein yields without 394 any negative influence on the allergens antigenicity.

396 Acknowledgments

397 This study was supported by the AiF-project AiF $14805 \mathrm{~N}$ (AiF: Arbeitsgemeinschaft 398 industrieller Forschungsvereinigungen). Special thanks go to B. Jacobsen, K. Ramcke and S. 399 Schwarz for technical support.

400

401 References

402 Besler M, Steinhart H, Paschke A. 2001. Stability of food allergens and allergenicity of 403 processed foods. J Chromatogr B Biomed Sci Appl. 756: 207-228.

404 Bradford MM. 1976. A rapid and sensitive method for the quantitation of microgram 405 quantities of protein utilizing the principle of protein-dye binding. Anal Biochem. 72: $406 \quad 248-54$.

407 Coca AF. 1922. Studies in specific hypersensitiveness. V. The preparation of fluid extracts 408 and solutions for use in the diagnosis and treatment of the allergies with notes on the $409 \quad$ collection of pollens. J Immunol. 7: 163-78.

410 Davis PJ, Smales CM, James DC. 2001. How can thermal processing modify the antigenicity 411 of proteins? Allergy. 56 Suppl 67: 56-60.

412 Fernandez SS, Padilla AP, Mucciarelli S. 1999. Protein extraction from Atriplex lampa 413 leaves: potential use as forage for animals used for human diets. Plant Foods Hum $414 \quad$ Nutr. 54: 251-259.

415 Hefle SL, Taylor SL. 2004. Food allergy and the food industry. Curr Allergy Asthma Rep. 4: $416 \quad 55-9$. 
417 Hefle SL, Lambrecht DM. 2004. Validated sandwich enzyme-linked immunosorbent assay for 418 casein and its application to retail and milk-allergic complaint foods. J Food Prot. 67: 419 1933-1938.

420 Heukeshoven J, Dernick R. 1986. Neue Ergebnisse zum Mechanismus der Silberfärbung. 421 Paper presented at: Electrophoresis Forum '86; Technische Universität München.

422 Hildebrandt S, Steinhart H, Paschke A. 2008. Comparison of different extraction solutions for 423 the analysis of allergens in hen's egg. Food Chem. 108: 1088-1093.

424 Hirose J, Kitabatake N, Kimura A, Narita H. 2004. Recognition of native and/or thermally 425 induced denatured forms of the major food allergen, ovomucoid, by human $\lg E$ and 426 mouse monoclonal IgG antibodies. Biosc Biotechnol Biochem. 68: 2490-2497.

427 Howard SB, Twigg P, Baird JK, Meehan EJ. 1988. The solubility of hen egg-white lysozyme. $428 \quad$ J Cryst Growth. 90: 94-104.

429 Kato Y, Oozawa E, Matsuda T. 2001a. Decrease in antigenic and allergenic potentials of 430 ovomucoid by heating in the presence of wheat flour: dependence on wheat variety 431 and intermolecular disulfide bridges. J Agric Food Chem. 49: 3661-3665.

432 Kato Y, Suginohara K, Fujiwara M. 2001b. A novel and simple method of insolubilization of 433 ovomucoid in cookies prepared from batter containing egg white. Food Sci Technol $434 \quad$ Res. 7: 35-38.

435 Langeland T. 1982. A clinical and immunological study of allergy to hen's egg white. II. $436 \quad$ Antigens in hen's egg white studied by crossed immunoelectrophoresis (CIE). Allergy. 437 37: $323-33$.

438 Leduc V, Demeulemester C, Polack B, Guizard C, Le Guern L, Peltre G. 1999. 439 Immunochemical detection of egg-white antigens and allergens in meat products. $440 \quad$ Allergy (Copenhagen). 54: 464-472.

441 Lowry OH, Rosebrough NJ, Farr AL, Randall RJ. 1951. Protein measurement with the Folin $442 \quad$ phenol reagent. J Biol Chem. 193: 265-75. 
443 Moneret-Vautrin DA, Kanny G. 2004. Update on threshold doses of food allergens: 444 Implications for patients and the food industry. Curr Opin Allergy Clin Immunol. 4: $445 \quad 215-219$.

446 Natarajan S, Xu C, Caperna TJ, Garrett WM. 2005. Comparison of protein solubilization 447 methods suitable for proteomic analysis of soybean seed proteins. Anal Biochem. $448 \quad 342: 214-220$.

449 Schubert S. 2003. Charakterisierung und Isolierung von Allergenen der Tomate 450 (Lycopersicon lycopersicum (L.) Karst. ex Farw.) [dissertation]. [Institut für Biochemie $451 \quad$ und Lebensmittelchemie]: Universität Hamburg.

452 Vieluf I, Besler M, Paschke A, Steinhart H, Vieluf D. 2002. Practical approach to adverse 453 food reactions. New Trends in Allergy V, 5th, Davos, Switzerland, Sept. 15-17, 2000. $454 \quad 190-202$.

455 Yeung JM, Newsome WH, Abbott MA. 2000. Determination of egg proteins in food products 456 by enzyme immunoassay. J AOAC Int. 83: 139-143. 
Table 1: Protein recovery rates (\%) estimated using different extractants to isolate milk proteins out of milk material or out of milk material in matrix $(\mathrm{WM}=$ without matrix $; \mathrm{WS}=$ wheat starch; FP $=$ fat powder; $\mathrm{CM}=$ cake mix $)$

\begin{tabular}{|c|c|c|c|c|c|c|c|c|c|c|c|c|}
\hline \multirow{2}{*}{ Milk material } & \multirow{2}{*}{ Matrix } & \multicolumn{11}{|c|}{ Extractant } \\
\hline & & $A$ & $B$ & $\mathrm{C}$ & $\mathrm{D}$ & $E$ & $\mathrm{~F}$ & G & $\mathrm{H}$ & $\mathrm{I}$ & $\mathrm{J}$ & $\mathrm{K}$ \\
\hline \multirow{4}{*}{ milk powder } & WM & $88 \pm 4$ & $85 \pm 3$ & $90 \pm 2$ & $89 \pm 3$ & $85 \pm 2$ & $86 \pm 3$ & $16 \pm 1$ & $69 \pm 4$ & $109 \pm 4$ & $94 \pm 4$ & $86 \pm 8$ \\
\hline & WS & $87 \pm 1$ & $91 \pm 4$ & $92 \pm 4$ & $88 \pm 4$ & $79 \pm 7$ & - & $10 \pm 0$ & $69 \pm 4$ & $116 \pm 6$ & $92 \pm 5$ & $89 \pm 2$ \\
\hline & FP & $86 \pm 3$ & $79 \pm 5$ & $83 \pm 5$ & $98 \pm 5$ & $44 \pm 0$ & - & $27 \pm 5$ & $78 \pm 2$ & $106 \pm 4$ & $85 \pm 5$ & $88 \pm 2$ \\
\hline & $\mathrm{CM}$ & $71 \pm 4$ & $82 \pm 9$ & $72 \pm 13$ & $87 \pm 13$ & $40 \pm 3$ & - & $14 \pm 0$ & $81 \pm 3$ & $74 \pm 5$ & $82 \pm 8$ & $74 \pm 4$ \\
\hline \multirow{4}{*}{ Sweet whey } & WM & $81 \pm 1$ & $85 \pm 3$ & $91 \pm 3$ & $92 \pm 3$ & $85 \pm 3$ & $97 \pm 4$ & $53 \pm 1$ & $37 \pm 1$ & $138 \pm 12$ & $112 \pm 3$ & $85 \pm 4$ \\
\hline & WS & $81 \pm 4$ & $89 \pm 7$ & $90 \pm 1$ & $93 \pm 1$ & $89 \pm 6$ & 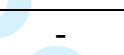 & $45 \pm 3$ & $36 \pm 1$ & $142 \pm 4$ & $105 \pm 2$ & $91 \pm 8$ \\
\hline & FP & $80 \pm 1$ & $84 \pm 5$ & $80 \pm 2$ & $101 \pm 2$ & $47 \pm 3$ & - & $65 \pm 11$ & $42 \pm 1$ & $87 \pm 1$ & $92 \pm 3$ & $95 \pm 2$ \\
\hline & $\mathrm{CM}$ & $83 \pm 4$ & $84 \pm 3$ & $63 \pm 10$ & $110 \pm 10$ & $47 \pm 2$ & - & $77 \pm 4$ & $32 \pm 3$ & $75 \pm 2$ & $86 \pm 6$ & $89 \pm 5$ \\
\hline \multirow{4}{*}{ Acid whey } & WM & $99 \pm 10$ & $95 \pm 1$ & $102 \pm 3$ & $79 \pm 3$ & $79 \pm 2$ & $93 \pm 4$ & $41 \pm 2$ & $46 \pm 0$ & $140 \pm 6$ & $112 \pm 5$ & $60 \pm 3$ \\
\hline & WS & $94 \pm 5$ & $107 \pm 9$ & $106 \pm 7$ & $59 \pm 7$ & $83 \pm 3$ & - & $31 \pm 2$ & $55 \pm 3$ & $137 \pm 9$ & $113 \pm 8$ & $30 \pm 1$ \\
\hline & FP & $81 \pm 2$ & $82 \pm 1$ & $79 \pm 6$ & $96 \pm 6$ & $41 \pm 2$ & - & $71 \pm 2$ & $43 \pm 2$ & $96 \pm 3$ & $91 \pm 2$ & $30 \pm 2$ \\
\hline & $\mathrm{CM}$ & $81 \pm 1$ & $81 \pm 3$ & $82 \pm 12$ & $101 \pm 12$ & $47 \pm 2$ & - & $97 \pm 1$ & $44 \pm 1$ & $87 \pm 2$ & $91 \pm 5$ & $66 \pm 5$ \\
\hline
\end{tabular}


Table 2: Protein recovery rates (\%) estimated using different extractants to isolate egg proteins out of egg material or out of egg material in matrix $(\mathrm{WM}=$ without matrix; $\mathrm{WS}=$ wheat starch; FP = fat powder; $\mathrm{CM}=$ cake mix $)$

\begin{tabular}{|c|c|c|c|c|c|c|c|c|c|c|c|c|c|}
\hline & & 1 & 2 & 3 & 4 & 5 & 6 & 7 & 8 & 9 & 10 & 11 & 12 \\
\hline \multirow{4}{*}{ Whole egg } & WM & $27 \pm 2$ & $26 \pm 2$ & $20 \pm 1$ & $23 \pm 2$ & $108 \pm 3$ & $74 \pm 5$ & $26 \pm 1$ & $22 \pm 1$ & $119 \pm 11$ & $112 \pm 3$ & $64 \pm 2$ & 87 \\
\hline & WS & $22 \pm 1$ & $22 \pm 2$ & $22 \pm 2$ & $21 \pm 1$ & $108 \pm 10$ & - & $21 \pm 2$ & $27 \pm 2$ & $100 \pm 4$ & $117 \pm 4$ & $70 \pm 0$ & 84 \\
\hline & FP & $20 \pm 1$ & $22 \pm 1$ & $18 \pm 2$ & $41 \pm 2$ & $75 \pm 1$ & - & $22 \pm 2$ & $30 \pm 2$ & $125 \pm 0$ & $134 \pm 5$ & $64 \pm 6$ & 97 \\
\hline & $\mathrm{CM}$ & $29 \pm 2$ & $25 \pm 1$ & $21 \pm 4$ & $28 \pm 3$ & $78 \pm 1$ & - & $27 \pm 3$ & $30 \pm 3$ & $100 \pm 2$ & $124 \pm 4$ & $45 \pm 2$ & 112 \\
\hline \multirow{4}{*}{ Egg yolk } & WM & $37 \pm 2$ & $36 \pm 1$ & $38 \pm 0$ & $30 \pm 2$ & $86 \pm 0$ & $63 \pm 4$ & $79 \pm 2$ & $49 \pm 2$ & $129 \pm 6$ & $113 \pm 5$ & $16 \pm 0$ & 71 \\
\hline & WS & $38 \pm 1$ & $38 \pm 2$ & $39 \pm 4$ & $30 \pm 2$ & $83 \pm 4$ & - & $62 \pm 1$ & $45 \pm 1$ & $111 \pm 9$ & $108 \pm 2$ & $20 \pm 1$ & 73 \\
\hline & FP & $81 \pm 6$ & $70 \pm 4$ & $70 \pm 11$ & $75 \pm 4$ & $77 \pm 2$ & - & $86 \pm 6$ & $33 \pm 2$ & $151 \pm 9$ & $139 \pm 4$ & $94 \pm 7$ & 90 \\
\hline & $\mathrm{CM}$ & $38 \pm 2$ & $38 \pm 1$ & $50 \pm 3$ & $45 \pm 4$ & $85 \pm 5$ & - & $107 \pm 8$ & $35 \pm 3$ & $113 \pm 12$ & $133 \pm 6$ & $51 \pm 1$ & 83 \\
\hline \multirow{4}{*}{ Egg white } & WM & $76 \pm 2$ & $76 \pm 7$ & $61 \pm 11$ & $53 \pm 1$ & $121 \pm 3$ & $116 \pm 8$ & $37 \pm 2$ & $20 \pm 0$ & $138 \pm 16$ & $123 \pm 5$ & $77 \pm 2$ & 86 \\
\hline & WS & $76 \pm 3$ & $79 \pm 1$ & $71 \pm 1$ & $69 \pm 1$ & $120 \pm 3$ & - & $39 \pm 1$ & $21 \pm 2$ & $135 \pm 9$ & $132 \pm 2$ & $88 \pm 2$ & 95 \\
\hline & FP & $15 \pm 1$ & $14 \pm 0$ & $19 \pm 0$ & $16 \pm 0$ & $90 \pm 1$ & - & $39 \pm 2$ & $32 \pm 1$ & $130 \pm 10$ & $145 \pm 4$ & $24 \pm 2$ & 111 \\
\hline & $\mathrm{CM}$ & $16 \pm 2$ & $19 \pm 2$ & $22 \pm 8$ & $26 \pm 4$ & $78 \pm 0$ & - & $52 \pm 6$ & $44 \pm 1$ & $120 \pm 4$ & $141 \pm 9$ & $41 \pm 2$ & 102 \\
\hline
\end{tabular}


Table 3: Protein recovery rates (\%) using solution I and J, respectively, at different $\mathrm{pH}$-values to isolate milk proteins from milk material and from milk material in certain matrices at different temperatures. $(\mathrm{WM}=$ without matrix; $\mathrm{WS}=$ wheat starch; $\mathrm{CM}=$ cake $\mathrm{mix})$

\begin{tabular}{|c|c|c|c|c|c|c|}
\hline \multirow{2}{*}{$\begin{array}{l}\text { Dry milk } \\
\text { material }\end{array}$} & \multirow{2}{*}{ Extractant } & \multirow{2}{*}{ Matrix } & \multirow{2}{*}{$\mathrm{pH}$} & \multicolumn{3}{|c|}{ Recovery rates [\%] } \\
\hline & & & & $4^{\circ} \mathrm{C}$ & RT & $40^{\circ} \mathrm{C}$ \\
\hline \multirow{14}{*}{ Milk powder } & \multirow{7}{*}{ I } & \multirow{3}{*}{ WM } & 7.4 & $95 \pm 6$ & $103 \pm 5$ & $96 \pm 4$ \\
\hline & & & 9.4 & $72 \pm 7$ & $82 \pm 9$ & $89 \pm 7$ \\
\hline & & & 11.4 & $90 \pm 4$ & $91 \pm 2$ & $95 \pm 3$ \\
\hline & & \multirow{2}{*}{ WS } & 7.4 & $95 \pm 2$ & $71 \pm 4$ & $85 \pm 6$ \\
\hline & & & 9.4 & $63 \pm 4$ & $59 \pm 2$ & $68 \pm 6$ \\
\hline & & \multirow{2}{*}{ CM } & 7.4 & $97 \pm 2$ & $89 \pm 1$ & $89 \pm 3$ \\
\hline & & & 9.4 & $60 \pm 3$ & $62 \pm 6$ & $57 \pm 5$ \\
\hline & \multirow{7}{*}{$\mathrm{J}$} & \multirow{3}{*}{ WM } & 8.5 & $73 \pm 3$ & $75 \pm 5$ & $74 \pm 5$ \\
\hline & & & 10.5 & $83 \pm 2$ & $83 \pm 3$ & $78 \pm 3$ \\
\hline & & & 12.5 & $99 \pm 2$ & $93 \pm 4$ & $90 \pm 5$ \\
\hline & & \multirow{2}{*}{ WS } & 8.5 & $90 \pm 1$ & $96 \pm 6$ & $96 \pm 5$ \\
\hline & & & 10.5 & $92 \pm 4$ & $91 \pm 5$ & $92 \pm 1$ \\
\hline & & \multirow{2}{*}{ CM } & 8.5 & $98 \pm 3$ & $97 \pm 5$ & $99 \pm 6$ \\
\hline & & & 10.5 & $112 \pm 7$ & $108 \pm 2$ & $115 \pm 6$ \\
\hline \multirow{14}{*}{ Sweet whey } & \multirow{7}{*}{ I } & \multirow{3}{*}{ WM } & 7.4 & $85 \pm 2$ & $87 \pm 3$ & $100 \pm 3$ \\
\hline & & & 9.4 & $82 \pm 1$ & $90 \pm 3$ & $79 \pm 6$ \\
\hline & & & 11.4 & $111 \pm 4$ & $107 \pm 1$ & $105 \pm 2$ \\
\hline & & \multirow{2}{*}{ WS } & 7.4 & $80 \pm 5$ & $70 \pm 4$ & $80 \pm 3$ \\
\hline & & & 9.4 & $76 \pm 6$ & $87 \pm 5$ & $81 \pm 3$ \\
\hline & & \multirow{2}{*}{ CM } & 7.4 & $89 \pm 3$ & $83 \pm 3$ & $87 \pm 1$ \\
\hline & & & 9.4 & $76 \pm 3$ & $70 \pm 1$ & $75 \pm 6$ \\
\hline & \multirow{7}{*}{$\mathrm{J}$} & \multirow{3}{*}{ WM } & 8.5 & $67 \pm 3$ & $72 \pm 1$ & $77 \pm 4$ \\
\hline & & & 10.5 & $88 \pm 0$ & $91 \pm 1$ & $89 \pm 4$ \\
\hline & & & 12.5 & $129 \pm 11$ & $118 \pm 11$ & $110 \pm 2$ \\
\hline & & \multirow{2}{*}{ WS } & 8.5 & $103 \pm 5$ & $102 \pm 3$ & $109 \pm 7$ \\
\hline & & & 10.5 & $101 \pm 1$ & $100 \pm 1$ & $101 \pm 1$ \\
\hline & & \multirow{2}{*}{ CM } & 8.5 & $113 \pm 4$ & $111 \pm 1$ & $114 \pm 1$ \\
\hline & & & 10.5 & $118 \pm 2$ & $113 \pm 2$ & $111 \pm 1$ \\
\hline \multirow{14}{*}{ Acid whey } & & & 7.4 & $81 \pm 5$ & $95 \pm 2$ & $96 \pm 1$ \\
\hline & & WM & 9.4 & $91 \pm 1$ & $91 \pm 10$ & $89 \pm 4$ \\
\hline & & & 11.4 & $109 \pm 6$ & $128 \pm 12$ & $109 \pm 8$ \\
\hline & I & WS & 7.4 & $84 \pm 3$ & $87 \pm 4$ & $87 \pm 3$ \\
\hline & & VWS & 9.4 & $81 \pm 2$ & $49 \pm 5$ & $88 \pm 7$ \\
\hline & & CM & 7.4 & $80 \pm 7$ & $97 \pm 4$ & $95 \pm 3$ \\
\hline & & UIVI & 9.4 & $87 \pm 7$ & $85 \pm 4$ & $86 \pm 2$ \\
\hline & & & 8.5 & $71 \pm 2$ & $75 \pm 4$ & $76 \pm 1$ \\
\hline & & WM & 10.5 & $87 \pm 2$ & $98 \pm 6$ & $83 \pm 2$ \\
\hline & & & 12.5 & $113 \pm 2$ & $113 \pm 3$ & $101 \pm 4$ \\
\hline & $J$ & WS & 8.5 & $100 \pm 2$ & $102 \pm 2$ & $101 \pm 3$ \\
\hline & & VVS & 10.5 & $96 \pm 3$ & $100 \pm 5$ & $101 \pm 1$ \\
\hline & & & 8.5 & $118 \pm 12$ & $115 \pm 4$ & $111 \pm 3$ \\
\hline & & CIVI & 10.5 & $108 \pm 2$ & $119 \pm 7$ & $108 \pm 11$ \\
\hline
\end{tabular}


Table 4: Protein recovery rates (\%) using solution I and J, respectively, at different $\mathrm{pH}$-values to isolate egg proteins from egg material and from egg material in certain matrices at different temperatures. $(\mathrm{WM}=$ without matrix; $\mathrm{WS}=$ wheat starch; $\mathrm{CM}=$ cake $\mathrm{mix})$

\begin{tabular}{|c|c|c|c|c|c|c|}
\hline \multirow{2}{*}{$\begin{array}{l}\text { Dry egg } \\
\text { material }\end{array}$} & \multirow{2}{*}{ Extractant } & \multirow{2}{*}{ Matrix } & \multirow{2}{*}{$\mathrm{pH}$} & \multicolumn{3}{|c|}{ Recovery rates [\%] } \\
\hline & & & & $4^{\circ} \mathrm{C}$ & RT & $40^{\circ} \mathrm{C}$ \\
\hline \multirow{14}{*}{ Whole egg } & \multirow{7}{*}{ I } & \multirow{3}{*}{ WM } & 7.4 & $94 \pm 1$ & $89 \pm 7$ & $99 \pm 5$ \\
\hline & & & 9.4 & $102 \pm 4$ & $98 \pm 8$ & $101 \pm 2$ \\
\hline & & & 11.4 & $110 \pm 3$ & $103 \pm 4$ & $94 \pm 6$ \\
\hline & & \multirow{2}{*}{ WS } & 7.4 & $93 \pm 4$ & $93 \pm 1$ & $92 \pm 4$ \\
\hline & & & 9.4 & $102 \pm 3$ & $101 \pm 1$ & $101 \pm 8$ \\
\hline & & \multirow{2}{*}{$\mathrm{CM}$} & 7.4 & $100 \pm 3$ & $105 \pm 9$ & $105 \pm 2$ \\
\hline & & & 9.4 & $105 \pm 1$ & $105 \pm 2$ & $106 \pm 3$ \\
\hline & \multirow{7}{*}{ J } & \multirow{3}{*}{ WM } & 8.5 & $114 \pm 3$ & $120 \pm 2$ & $126 \pm 4$ \\
\hline & & & 10.5 & $109 \pm 2$ & $117 \pm 3$ & $114 \pm 2$ \\
\hline & & & 12.5 & $110 \pm 3$ & $111 \pm 7$ & $111 \pm 6$ \\
\hline & & \multirow{2}{*}{ WS } & 8.5 & $111 \pm 5$ & $117 \pm 7$ & $114 \pm 9$ \\
\hline & & & 10.5 & $102 \pm 6$ & $108 \pm 4$ & $113 \pm 5$ \\
\hline & & \multirow{2}{*}{$\mathrm{CM}$} & 8.5 & $111 \pm 7$ & $113 \pm 5$ & $106 \pm 1$ \\
\hline & & & 10.5 & $92 \pm 4$ & $91 \pm 4$ & $100 \pm 2$ \\
\hline \multirow{14}{*}{ Egg white } & \multirow{7}{*}{ I } & \multirow{3}{*}{ WM } & 7.4 & $114 \pm 8$ & $109 \pm 9$ & $117 \pm 3$ \\
\hline & & & 9.4 & $116 \pm 4$ & $115 \pm 3$ & $127 \pm 6$ \\
\hline & & & 11.4 & $126 \pm 6$ & $123 \pm 7$ & $118 \pm 3$ \\
\hline & & \multirow{2}{*}{ WS } & 7.4 & $107 \pm 6$ & $115 \pm 5$ & $116 \pm 5$ \\
\hline & & & 9.4 & $123 \pm 7$ & $123 \pm 9$ & $126 \pm 1$ \\
\hline & & \multirow{2}{*}{$\mathrm{CM}$} & 7.4 & $114 \pm 2$ & $114 \pm 4$ & $121 \pm 7$ \\
\hline & & & 9.4 & $118 \pm 5$ & $120 \pm 4$ & $127 \pm 10$ \\
\hline & \multirow{7}{*}{$\mathrm{J}$} & \multirow{3}{*}{ WM } & 8.5 & $102 \pm 4$ & $122 \pm 2$ & $131 \pm 2$ \\
\hline & & & 10.5 & $119 \pm 7$ & $116 \pm 1$ & $126 \pm 6$ \\
\hline & & & 12.5 & $118 \pm 6$ & $124 \pm 6$ & $120 \pm 7$ \\
\hline & & \multirow{2}{*}{ WS } & 8.5 & $124 \pm 8$ & $119 \pm 8$ & $127 \pm 2$ \\
\hline & & & 10.5 & $126 \pm 4$ & $116 \pm 5$ & $119 \pm 3$ \\
\hline & & \multirow{2}{*}{ CM } & 8.5 & $123 \pm 11$ & $122 \pm 3$ & $118 \pm 5$ \\
\hline & & & 10.5 & $105 \pm 6$ & $109 \pm 6$ & $114 \pm 4$ \\
\hline \multirow{14}{*}{ Egg yolk } & & & 7.4 & $121 \pm 2$ & $121 \pm 2$ & $132 \pm 11$ \\
\hline & & WM & 9.4 & $125 \pm 10$ & $111 \pm 6$ & $103 \pm 5$ \\
\hline & & & 11.4 & $116 \pm 1$ & $111 \pm 7$ & $112 \pm 7$ \\
\hline & I & & 7.4 & $106 \pm 1$ & $101 \pm 0$ & $103 \pm 7$ \\
\hline & & WS & 9.4 & $118 \pm 7$ & $109 \pm 5$ & $114 \pm 8$ \\
\hline & & & 7.4 & $105 \pm 3$ & $106 \pm 3$ & $105 \pm 7$ \\
\hline & & CM & 9.4 & $115 \pm 3$ & $121 \pm 7$ & $113 \pm 2$ \\
\hline & & & 8.5 & $108 \pm 1$ & $110 \pm 10$ & $121 \pm 8$ \\
\hline & & WM & 10.5 & $117 \pm 2$ & $113 \pm 1$ & $117 \pm 6$ \\
\hline & & & 12.5 & $103 \pm 6$ & $109 \pm 7$ & $105 \pm 3$ \\
\hline & $J$ & WS & 8.5 & $115 \pm 4$ & $112 \pm 3$ & $114 \pm 5$ \\
\hline & & WS & 10.5 & $111 \pm 1$ & $110 \pm 2$ & $111 \pm 4$ \\
\hline & & & 8.5 & $113 \pm 4$ & $113 \pm 10$ & $111 \pm 5$ \\
\hline & & CM & 10.5 & $92 \pm 6$ & $87 \pm 3$ & $96 \pm 6$ \\
\hline
\end{tabular}


Table 5: Protein recovery rates obtained by varied extraction durations at three temperatures using solution I $(\mathrm{pH} \mathrm{7.4)}$ and $\mathrm{J}(\mathrm{pH} 8.5)$ to isolate milk proteins from skim milk $(\mathrm{WM}=$ without matrix; $\mathrm{CM}=$ cake $\mathrm{mix}$ ).

\begin{tabular}{|c|c|c|c|c|c|c|c|c|}
\hline \multirow{2}{*}{ Extractant } & \multirow{2}{*}{ Matrix } & \multirow{2}{*}{ Temp. } & \multicolumn{6}{|c|}{ Extraction duration [h] } \\
\hline & & & 0 & 0.5 & 1 & 2 & 4 & 8 \\
\hline \multirow{6}{*}{$\begin{array}{c}\mathrm{J} \\
(\mathrm{pH} 8.5)\end{array}$} & \multirow{3}{*}{ WM } & $4{ }^{\circ} \mathrm{C}$ & \multirow{3}{*}{$81 \pm 1$} & $82 \pm 0$ & $90 \pm 1$ & $85 \pm 2$ & $85 \pm 6$ & $82 \pm 2$ \\
\hline & & RT & & $81 \pm 2$ & $97 \pm 1$ & $89 \pm 3$ & $80 \pm 7$ & $85 \pm 4$ \\
\hline & & $40^{\circ} \mathrm{C}$ & & $82 \pm 3$ & $89 \pm 3$ & $78 \pm 1$ & $82 \pm 3$ & $84 \pm 3$ \\
\hline & \multirow{3}{*}{ CM } & $4^{\circ} \mathrm{C}$ & \multirow{3}{*}{$80 \pm 1$} & $89 \pm 8$ & $98 \pm 3$ & $92 \pm 7$ & $99 \pm 2$ & $88 \pm 5$ \\
\hline & & RT & & $80 \pm 6$ & $90 \pm 9$ & $98 \pm 5$ & $75 \pm 7$ & $86 \pm 0$ \\
\hline & & $40^{\circ} \mathrm{C}$ & & $82 \pm 4$ & $88 \pm 7$ & $87 \pm 1$ & $96 \pm 2$ & $91 \pm 7$ \\
\hline \multirow{6}{*}{$\begin{array}{c}\mathrm{I} \\
(\mathrm{pH} 7.4)\end{array}$} & \multirow{3}{*}{ WM } & $4^{\circ} \mathrm{C}$ & \multirow{3}{*}{$96 \pm 1$} & $88 \pm 1$ & $101 \pm 9$ & $84 \pm 2$ & $86 \pm 1$ & $82 \pm 0$ \\
\hline & & RT & & $94 \pm 2$ & $102 \pm 4$ & $86 \pm 0$ & $114 \pm 9$ & $86 \pm 1$ \\
\hline & & $40^{\circ} \mathrm{C}$ & & $84 \pm 7$ & $112 \pm 8$ & $83 \pm 1$ & $87 \pm 1$ & $88 \pm 8$ \\
\hline & \multirow{3}{*}{ CM } & $4^{\circ} \mathrm{C}$ & \multirow{3}{*}{$78 \pm 4$} & $90 \pm 4$ & $83 \pm 1$ & $80 \pm 5$ & $86 \pm 2$ & $83 \pm 1$ \\
\hline & & RT & & $80 \pm 0$ & $90 \pm 6$ & $83 \pm 4$ & $80 \pm 6$ & $77 \pm 7$ \\
\hline & & $40^{\circ} \mathrm{C}$ & & $83 \pm 3$ & $92 \pm 5$ & $76 \pm 7$ & $93 \pm 9$ & $78 \pm 3$ \\
\hline
\end{tabular}


Table 6: Protein recovery rates obtained by varied extraction durations at three temperatures using solution $\mathrm{I}$ and $\mathrm{J}$ to isolate egg proteins from whole egg powder $(\mathrm{WM}=$ without matrix; $\mathrm{CM}=$ cake $\operatorname{mix})$.

\begin{tabular}{|c|c|c|c|c|c|c|c|c|}
\hline \multirow{2}{*}{ Extractant } & \multirow{2}{*}{ Matrix } & \multirow{2}{*}{ Temp. } & \multicolumn{6}{|c|}{ Extraction duration [h] } \\
\hline & & & 0 & 0.5 & 1 & 2 & 4 & 8 \\
\hline \multirow{6}{*}{$\begin{array}{c}\mathrm{J} \\
(\mathrm{pH} 8.5)\end{array}$} & \multirow{3}{*}{ WM } & $4{ }^{\circ} \mathrm{C}$ & \multirow{3}{*}{$107 \pm 4$} & $106 \pm 5$ & $105 \pm 1$ & $104 \pm 4$ & $106 \pm 3$ & $104 \pm 4$ \\
\hline & & RT & & $110 \pm 3$ & $108 \pm 3$ & $104 \pm 2$ & $104 \pm 1$ & $109 \pm 2$ \\
\hline & & $40^{\circ} \mathrm{C}$ & & $110 \pm 0$ & $109 \pm 2$ & $109 \pm 4$ & $106 \pm 3$ & $107 \pm 1$ \\
\hline & \multirow{3}{*}{ CM } & $4{ }^{\circ} \mathrm{C}$ & \multirow{3}{*}{$115 \pm 6$} & $116 \pm 6$ & $105 \pm 3$ & $112 \pm 1$ & $105 \pm 4$ & $113 \pm 8$ \\
\hline & & RT & & $119 \pm 12$ & $117 \pm 5$ & $112 \pm 4$ & $111 \pm 3$ & $112 \pm 6$ \\
\hline & & $40^{\circ} \mathrm{C}$ & & $116 \pm 0$ & $122 \pm 3$ & $120 \pm 2$ & $123 \pm 0$ & $111 \pm 6$ \\
\hline \multirow{6}{*}{$\begin{array}{c}\mathrm{I} \\
(\mathrm{pH} 7.4)\end{array}$} & \multirow{3}{*}{ WM } & $4{ }^{\circ} \mathrm{C}$ & \multirow{3}{*}{$94 \pm 6$} & $96 \pm 2$ & $99 \pm 2$ & $99 \pm 5$ & $104 \pm 2$ & $104 \pm 3$ \\
\hline & & RT & & $96 \pm 4$ & $93 \pm 3$ & $98 \pm 2$ & $94 \pm 3$ & $96 \pm 6$ \\
\hline & & $40^{\circ} \mathrm{C}$ & & $99 \pm 3$ & $103 \pm 3$ & $95 \pm 2$ & $101 \pm 0$ & $101 \pm 3$ \\
\hline & \multirow{3}{*}{ CM } & $4^{\circ} \mathrm{C}$ & \multirow{3}{*}{$91 \pm 2$} & $92 \pm 1$ & $93 \pm 1$ & $92 \pm 1$ & $89 \pm 6$ & $91 \pm 0$ \\
\hline & & RT & & $90 \pm 0$ & $99 \pm 1$ & $93 \pm 2$ & $94 \pm 4$ & $93 \pm 5$ \\
\hline & & $40^{\circ} \mathrm{C}$ & & $112 \pm 3$ & $112 \pm 6$ & $117 \pm 3$ & $117 \pm 2$ & $108 \pm 0$ \\
\hline
\end{tabular}


1 Fig. 1: LDS - PAGE and silver staining patterns of proteins extracted from egg powder (left)

2 and milk powder (right), respectively, using different extractants. MW: molecular weight 3 marker; CON: Conalbumin (76 kDa); OVA: Ovalbumin (44.5 kDa); OVO: Ovomucoid (28 4 kDa); LYS: Lysozyme (14.3 kDa); BSA: Bovine serum albumin (66.3 kDa); CAS: Caseins 5 (20.6 -25.2 kDa); LG: $\beta$-lactoglobulin (18.3 kDa); LA: $\alpha$-lactalbumin (14.2 kDa).

6

7 Fig. 2: LDS - PAGE and silver staining patterns of proteins extracted from egg powder using 8 solution $\mathrm{J}$ (left) and $\mathrm{I}$ (right), respectively, adjusted to different $\mathrm{pH}$-values and used for 9 extraction at $4{ }^{\circ} \mathrm{C}$, room temperature $(\mathrm{RT})$ and $40{ }^{\circ} \mathrm{C}$. MW: molecular weight marker; CON: 10 Conalbumin (76 kDa); OVA: Ovalbumin (44.5 kDa); OVO: Ovomucoid (28 kDa); LYS: 11 Lysozyme (14.3 kDa).

13 Fig. 3: Left: LDS - PAGE and Immunoblotting of ovalbumin extracted from egg powder using 14 different extractants and detection via anti-ovalbumin antibody. Right: LDS - PAGE and 15 Immunoblotting of casein extracted from milk powder using different extractants and 16 detection via anti-casein antibody. MW: molecular weight marker; CON: Conalbumin (76 17 kDa); OVA: Ovalbumin (44.5 kDa); OVO: Ovomucoid (28 kDa); LYS: Lysozyme (14.3 kDa); 18 BSA: Bovine serum albumin (66.3 kDa); CAS: Casein (20.6 -25.2 kDa).

20 Fig. 4: Left: LDS - PAGE and Immunoblotting of ovalbumin extracted from egg powder out of 21 dry cake mix as matrix using different extractants and detection via anti-ovalbumin antibody. 22 Right: LDS - PAGE and Immunoblotting of casein extracted from milk powder out of dry cake 23 mix as matrix using different extractants and detection via anti-casein antibody. MW: 24 molecular weight marker; CON: Conalbumin (76 kDa); OVA: Ovalbumin (44.5 kDa); OVO: 25 Ovomucoid (28 kDa); LYS: Lysozyme (14.3 kDa); BSA: Bovine serum albumin (66.3 kDa); 26 CAS: Casein (20.6 -25.3 kDa). 

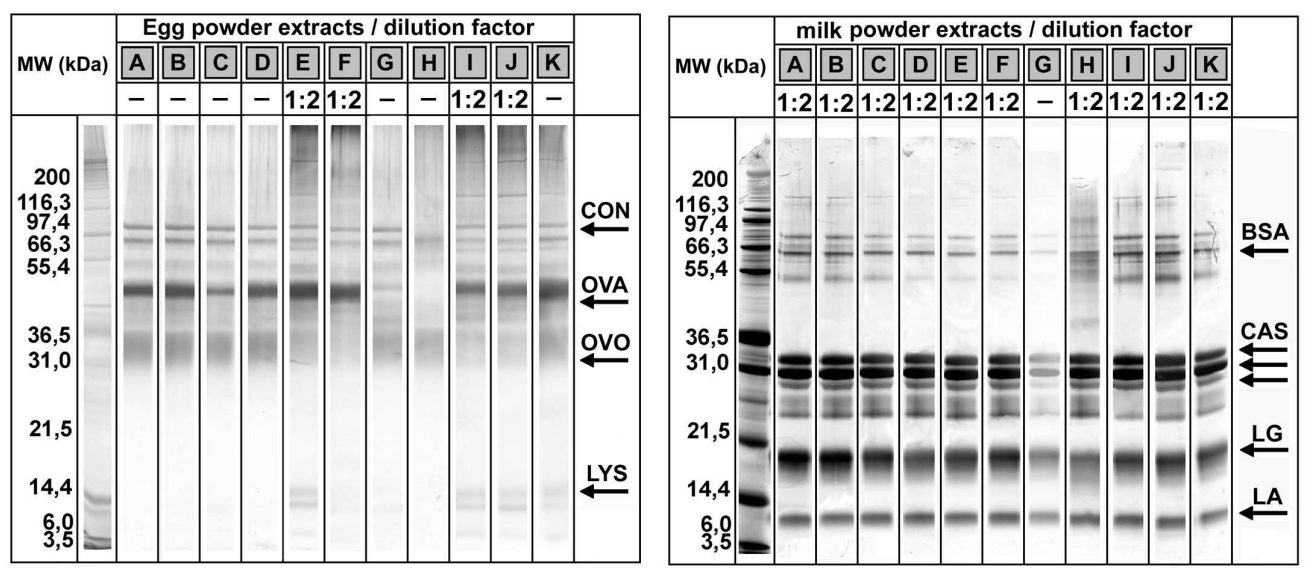

Figure 1

$299 \times 129 \mathrm{~mm}(183 \times 183 \mathrm{DPI})$ 

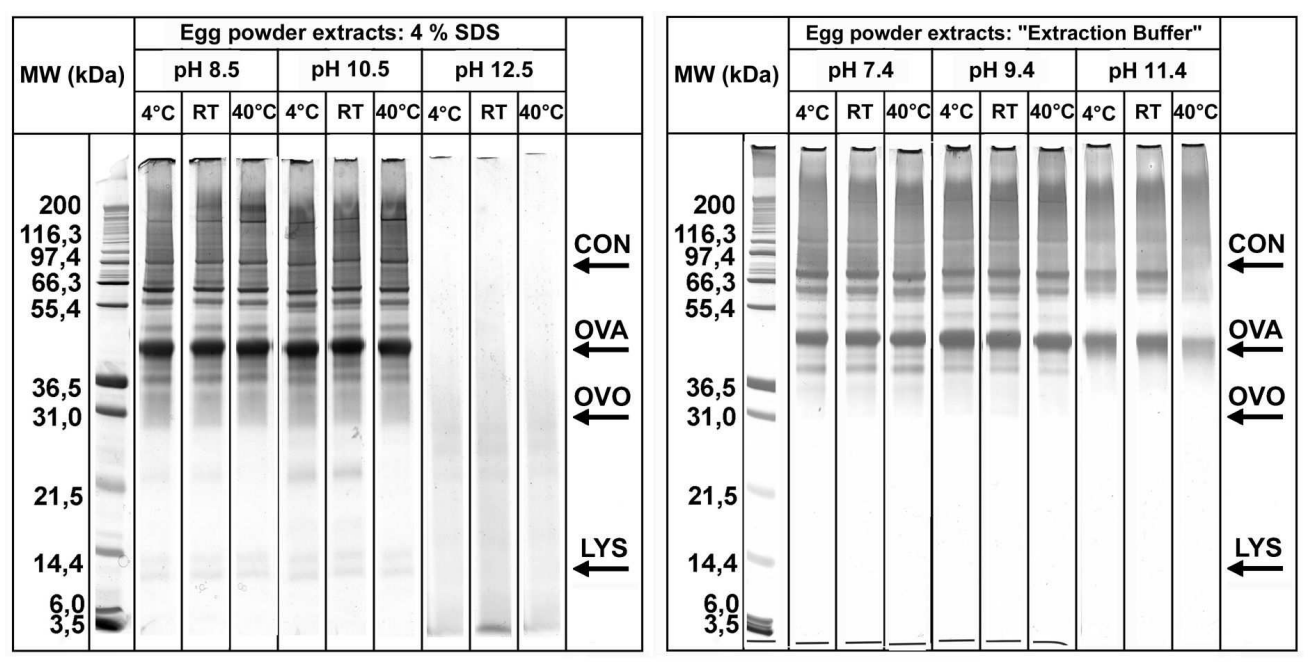

Figure 2

$259 \times 129 \mathrm{~mm}(183 \times 183 \mathrm{DPI})$ 


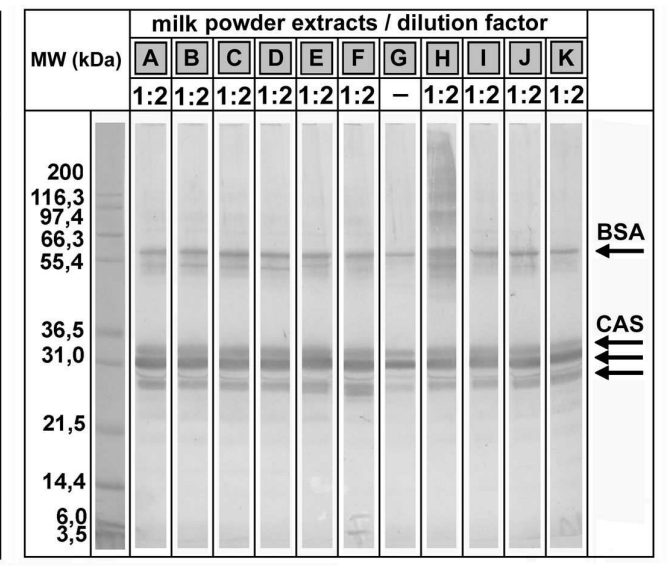

Figure 3 $299 \times 129 \mathrm{~mm}(183 \times 183 \mathrm{DPI})$ 


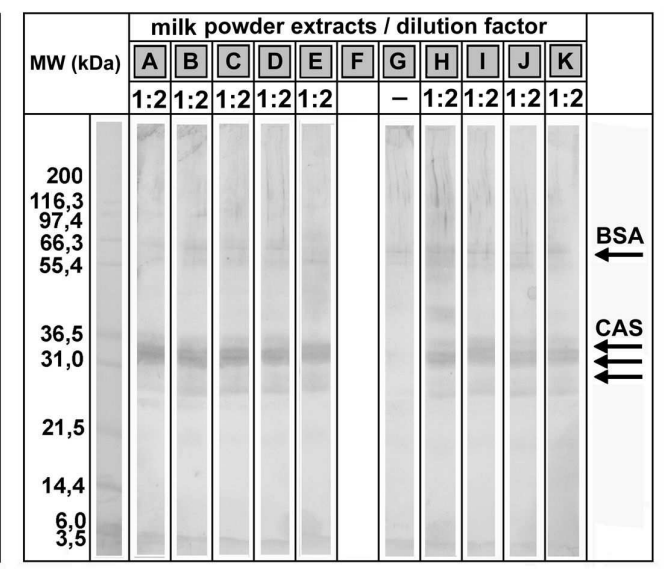

Figure 4 $299 \times 129 \mathrm{~mm}(183 \times 183 \mathrm{DPI})$ 